\title{
Food, gastronomy and cultural commons
}

\author{
Christian Barrère, Quentin Bonnard, Véronique Chossat, \\ Laboratoire Regards, Université de Reims Champagne Ardenne
}

In the 1970s Paul Bocuse, the famous French chef, created the V.G.E truffle soup, a luxury dish dedicated to the President of France at the time, Valéry Giscard d'Estaing, and named after his initials. It made the headlines of many newspapers and, a few months after, several restaurants, 'copying' Bocuse's creation, put V.G.E. soup, a truffle soup or a President soup on their menu.

In 2011, although French cuisine is often considered as the best in the world, The World's 50 Best Restaurant Awards ${ }^{1}$ gave a ranking of the best chefs putting 9 chefs from Denmark, Spain, Italy, Brazil and England before the first French one, Inaki Aizpitarte. At the same time, after the UNESCO featured "gastronomic meal of the French" on its list of the world's intangible heritage while some gastronomic experts published books and papers dealing with the decline or even the death of French cuisine.

Gastronomy and recipes are, at least for a part, shared resources and collective creations, which passed on over time. The problems above evoked are linked to the publicness of gastronomic resources. The aim of this chapter is to show that a cultural commons framework (cf. chapter one) is a powerful means of understanding the working and the dynamics of culinary cultures. For that we first consider the definition of culinary commons and heritage. Secondly we present their characteristics. Thirdly we are considering the first social dilemma defined in chapter one concerning the difference between using common resources and

\footnotetext{
${ }^{1}$ http://www.theworlds50best.com/awards/1-50-winners
} 
contributing to them. Then we observe a second dilemma related to the reproduction and the evolution of cultural culinary commons.

\section{Culinary commons and culinary heritage}

To define his menu a chef can choose among a lot of dishes; after, he can use a lot of recipes and ways of using food resources rooted in history: how to prepare a paella, a pizza, a hamburger and a lièvre à la royale. These resources (recipes, ways of using natural resources and so on) appear as shared resources. Moreover they are a special kind of commons. According to the English proverb frequently used by Elinor Ostrom, "the devil is in the details", the specificity of food and gastronomic commons has to be respected.

Firstly, culinary commons is not only a set of standard resources but is a cultural commons. From the beginning of humanity people seem to live in a social context: family, horde, clan, or tribe. The group's reproduction implies food and the earlier collective institutions emerge from the necessity of supporting life. Food has to be prepared; the invention of fire allows the cooking of foodstuffs and develops cultural constructions as shown by Levi-Strauss (1964). For him South American Indian cuisine is organized through the distinction between le cru (the raw), le cuit (the cooked) and le pourri (the putrefied) and this system of dynamic opposites orders so strongly the world by creating meaning that cooking can be viewed as the basis for thought. Thus, transforming natural resources into foodstuffs, according to norms, is 
a cultural and collective process, which constitutes a cultural commons in all the human societies.

Such cultural commons has at least three components:

- It concerns the selection of natural resources used in the food process. Fischler (1993) argues that the distinction between eatable and uneatable varies from country to country and from one culinary culture to another: in 42 cultures dog is commonly eaten, in a lot of them rats are very appreciated, ants are cooked in Colombia, bees, wasps and cockroaches in China. That means that such commons define the framework within which tastes and preferences can be displayed but, also, contribute to build an identity.

- It includes the ways of transforming resources by developing new resources on the basis of nature and culture: farming, selection of plants, breeding and so on.

- It also concerns the uses of resources: ways of preparing, preserving, cooking food, but also manners of eating and drinking.

Secondly, gastronomic commons is built on the basis of "culinary cultural commons". If, until the Renaissance, cuisine remained based on tradition and was conservative, it has nevertheless evolved and changed over time. Some components disappeared and new ones appeared. Culinary creation has for a long time been mainly collective, traditional and modest. Nevertheless, gastronomy, which differs from nutrition, appeared when people or groups could separate the nutritive function of food from its pleasure dimension. Then, in some countries (China, Japan, France, Italy and so on) or some areas (corresponding to regional or local cuisines), people developed culinary commons to the point of constituting gastronomic cultural commons. This evolution is strictly connected to culture: gastronomy 
belongs to the field of cultural and creative economy (cf. Chossat, 2001: 13; 2009: 129, Segers and Huijgh, 2007: 10, Throsby, 2010: 92 and Towse, 2010: 526) and to local cultures. Moreover, gastronomic commons develops and increases the heritage dimension of culinary commons. It crystallizes local specificities and identities. Gastronomy derives from two sources.

On the one hand, local cuisines evolved towards gastronomic services. On the basis of regional resources (truffles, fish or mushrooms for instance), of regional selection and elaboration (goose or duck confit, smoked or marinated fish), they defined regional recipes, for standard cuisine but also for ceremonies cuisine. Brueghel painted peasant feasts and showed people with a lot of different dishes. Popular gastronomy was not as marginal as it could seem to be: Bosch's paintings illustrating the Judgment Day or sins always used the figure of the gourmand, and on the religious frescos the gourmand, who was doomed to hell, was always present. All that indicates 'gluttony' was not uncommon.

On the second hand, some countries gave birth to aristocratic cuisines. Even if the Greeks and Romans knew gastronomy, classic gastronomy is mainly founded on the aristocratic model of gastronomy, connected to the European Court culture and mainly developed in the $17^{\text {th }}$ and $18^{\text {th }}$ Royal and Imperial Courts. The society of Louis XIV's Grand Siècle played an exceptional role in the building, normalization and export of this model. It constituted the basis of a gastronomic heritage (type of dishes, recipes, modes of presentation, crockery, ornamentation of the table...). During the $19^{\text {th }}$ century, it evolved towards an elitist model.

In the Middle Ages the aristocratic banquet was characterized by surfeit: plenty of dishes, scarce and expansive foodstuffs (fine wines, "noble" game - wild boar or stag but not rabbit -, and meat), waste. Aristocratic cuisine was conservative; the same dishes remained the 
symbols of luxury and distinguished them from the ordinary popular cuisine. But the society of the Court (Elias, 1973) drastically changed things. To dazzle the Grands, the Grand Cuisinier resorted to creativity: new recipes, new presentations, and new sauces. For that, he sought inspiration from the pre-existing gastronomic commons, but adding new recipes, he contributed to its expansion and reproduction. His name and his personality were included into the history of cuisine and melt into the aristocratic gastronomy. The chef is an object of envy among monarchs. Louis XIV contributed to create this movement by making cuisine a social issue as crucial to the court as fashion (Beaugé, 2010: 5). Some of the chefs had a key role in this development as, in the early 19th century, Antonin Carême (1783-1833) who realized "the reconfiguration of the aristocratic cuisine of the Ancien Régime into the elite and assertively national cuisine of the nineteenth century" (Parkhurst-Ferguson, 2004: 10). As Brillat-Savarin (1755-1826) he wrote not only for the aristocracy but also mainly for the bourgeois audience of urban connoisseurs. He cut with the extravagance of the Court cuisine but kept his inspiration in the old heritage of the aristocratic cuisine. Then the bourgeois cuisine could become a rationalized and euphemized form of the aristocratic one; more precisely it mixed popular gastronomy based on popular commons and aristocratic gastronomy based on aristocratic commons.

Today the elitist cuisine enhances the status of creativity. Cooking becomes "culinary creation" and art and the chef becomes an artist. Pierre Hermé, a famous French pastry cook, is named the "Picasso of pastry"2. Nevertheless creation uses the gastronomic heritages as a source of inspiration. The process of cooking is more and more similar to the creation in the Haute Couture industry; the chef has a status closer to the couturier-créateur's one. As a proof

\footnotetext{
2 See "Gastronomie : l'art et la manière", Label France $n^{\circ} 46$, edited by the Ministère des Affaires Etrangères, 2e trimestre 2002, Paris.
} 
chefs are more and more invited to art exhibitions (e.g. Ferran Adria in 2007 in Kassel, Germany), interviewed in art magazines (e.g. in 2008 a special issue of Artpress is dedicated to gastronomy and wine; in 2010 the French Fashion Institute -Institut français de la modeconsecrated a special issue of its research journal to cuisine and gastronomy) and so on.

Thirdly, culinary commons is a specific kind of commons for four main reasons:

- Some culinary commons is related to the identity of the group, in relation to other groups, and expresses its specificity through a collective idiosyncrasy (cf. chapter one). Fischler (1993) mentions that in popular language people are often designated by the special food they are supposed to like: in France, the Italians are named "macaroni" and the British persons "rosbif" when in England the French are "frogs" or "frog eaters".

- Generally, culinary commons is not a collection of resources but is structured by norms: for instance these norms define what must be eaten in the feasts and ceremonies in relation to the ordinary consumption of food; they define what luxury goods in relation to standard ones are. If, within a given community, food consumption is similar for a lot of people, it is not the case for everybody. Anthropologists have shown (Rappaport, 1984) that norms defined in diverse communities different kinds of food consumption according to status, age and gender. Similarly Douglas and Isherwood (Douglas, 1966; Douglas and Isherwood, 1979) showed that culinary taboos cannot be explained by sanitary reasons but derived from cultural choices3. Bourdieu (1979) systematically developed the idea

\footnotetext{
${ }^{3}$ « Instead of supposing that goods are primarily needed for subsistence plus competitive display, let us assume that they are needed for making visible and stable the categories of culture », Douglas and Isherwood, 1979: 59, quoted by Colloredo-Mansfeld, 2005: 215.
} 
that differences in consumptions, and correlatively differences in tastes and preferences, are structured in relation to one another; that may be applied to food practices and norms that belong to specific culinary commons.

- They result from a social and cultural building of local communities and societies. English cuisine is different from French and Italian cuisines, local and regional cuisines are also different. Their development paths are not the same; for instance national cuisines had strongly been influenced by the personality of some great Sovereigns (Queen Victoria or King Louis XIV), the organization of the Courts (the Court of Savoy, the Court of Versailles) and ideology (such as the domination of puritanism in some places, of libertine philosophy in others).

- They pass through time, by a process of cultural transmission, for instance through the conservation of the guild traditions and the mother-daughter transmission within families.

Then culinary and gastronomic commons are often more complex than a collection of resources. From a point of view, culinary and gastronomic commons collect a lot of shared resources coming from the whole world: recipes, knowledge, know-how, and organization of meals, service manners, and so on. Nevertheless, within this heterogeneous set, some subsets can be distinguished: the rules of Chinese cooking are not the same as the Italian ones. For instance the UNESCO has chosen the "gastronomic meal of the French" to feature on its list of the world's intangible heritage; according to the UNESCO experts, it means "a social custom aimed at celebrating the most important moments in the lives of individuals and groups" including for instance laying the table and matching the meal to the wine, and the menu composition. These subsets became local, regional or national heritages, according to 
the definition of heritage as "a set, connected to a titular (individual or group) and expressing its specificity, a set historically instituted of assets built and transmitted by the past, material and immaterial assets and institutions" (Barrère, 2004: 116). The concept of heritage underlines the historical dimension of culinary and gastronomic commons that determines their main characteristics.

\section{The characteristics of culinary commons and culinary heritage}

The management of culinary and gastronomic commons implies considering their cultural heritage dimension. For commonly shared natural resource, solutions are numerous and highly contextual. In the case of cultural commons, as the use of cultural resources is generally non rival, the problem is even more complex because the question is not to exploit natural resources avoiding waste and overuse but to produce and develop them (Madison, Frischmann and Strandburg, 2010). Moreover a lot of semi-commons or limited commons, using complex combinations of private, public and commons Property Rights (PR) are present in the cultural fields and highly contribute to the spillovers that characterize information and culture; the development of the web is now the main place for semi-commons. In the case of culinary commons, we have a twofold dimension: it is simultaneously shared resources and cultural heritage, and its value results from both of them. Everybody can use these resources; for instance, in any place in the world, one can propose a bouillabaisse using the recipe that originally was born in Marseille or sell a pizza, even far from Napoli. But chefs can benefit from the semiotic value of gastronomic heritage goods. A bouillabaisse is not only a recipe but carries image and reputation as it is related to a specific identity. It is the same for pizza: eating a pizza is not only eating dough, tomato and anchovy but also eating a piece of Italy and thinking of the Neapolitan sun. 
Culinary and gastronomic heritage is defined on time and on space. Heritage is the product of the past (a historical and not chronological time), through a building and a selection process: for instance, some very old recipes are kept, reproduced, developed and even normalized when other recipes are forgotten or scorned. It is also subject to evolution; present time can add new resources to it, for instance new recipes and new ways of cooking. Culture thus intervenes as a "new" cultural expression, a flow and a product of creativity, and an "old" culture -culture is a stock, in the form of heritage.

Heritage includes diverse components:

- Knowledge of a craft: for instance the knowledge of carving poultry;

- Creative knowledge: the ability to invent the VGE soup;

- Creative products: the recipes;

-Culinary and gastronomic styles: the service à la russe or the "gastronomic meal of the French";

-Tastes: gastronomy implies conventions to distinguish between good and bad taste;

- Reputation: as gastronomic services are a mix of foodstuffs and culture, they have symbolic values.

The spatial dimension of heritage derives from the connection between heritage and communities. While there exists a world set of gastronomic shared resources a large part of them are strongly linked to local cultures and communities and belong to specific heritages, to regional or local ways of cooking, largely dictating the way to make dishes, to associate flavours, to combine textures, and so on. 
Another important consequence of the spatial dimension of cultural gastronomic heritage is the constitution of gastronomic districts. Some of the resources of gastronomic heritage can be used in any place but most of them (it is as true for know-how as for natural products) have an idiosyncratic relation with territory. Then, ceteris paribus, their "productivity", which derives not only from their specific value, but also from their adequation with the consumer's tastes, is higher in some territories. This is attested by the spatial concentration of the restaurant industry shown by Bailly and Hussy (1991). The relation between gastronomic commons or local heritages and spatial location is nevertheless a complex and evolutionary one.

The French case gives some interesting observations. In 1990 the French dining establishments were mostly located along the "Diagonale Gourmande", which starts from Paris to Nice, through Lyon and Valence. In 2010, the distribution of restaurants changed somewhat. Now the five regions best equipped in restaurants are: Ile-de-France, Rhône-Alpes, Provence-Alpes-Côte d'Azur, Aquitaine and Bretagne. These regions dominate 'Gastronomic France' because they represent $51.4 \%$ of the total number of restaurants within the hexagon. According to the selection of the 2010 Michelin Guide, which concerns high quality restaurants (the "high-quality" segment of the restaurant market) we can see that five areas above named are particularly well endowed with stars. They represent almost a third (29\%) of the territory, and gather $57.4 \%$ of stars awarded in 2010 by the Red Guide $(66 \%$ of the 3 stars establishments, $73 \%$ restaurants of the 2 stars and $50 \%$ of establishments with 1 star). Therefore, there exists in France, areas where we find more restaurants than in others. Why?

Our five regions concentrate $46.4 \%$ of the French population and attract $52.4 \%$ of the tourists who come to France. Based on models of the new economic geography, today it is acknowledged that a larger and larger population is becoming a centripetal force for the 
economic development, due to the increasing diversity of jobs, products, incomes and demands it generates (Krugman, 1991; Helpman, 1998; Thisse and van Ypersele, 1999). Furthermore, with the development of tourism and mobility, Terrier (2006) argues that the present population in a given place at time $t$ can be different from the usual resident population in this area. Indeed, some geographic locations may have a comparative advantage because of the tourism demand that they drain, the presence of tourism infrastructure and important heritage tourism. Thus, the first explanation of the agglomeration of restaurants is on the demand side (Bailly and Paelinck, 1992) and especially the touristic demand, which creates substantial potential customers. From the supply side, the theory of Christaller (1933) is based on the distinction between the centres that are home for a supply of goods and services, and peripheries (complementary regions of the centre) where the demand resides. And according to Bilon-Hoefkens and Lefebvre (2004), Lösch (1940) developed a model that includes the theories of Von Thünen's agricultural location (1826), Weber's industrial location (1909), Cantillon's formation of cities (1755) and Christaller's central places theory (1933), to establish the city as a centre of attraction. The major force of agglomeration is producing by externalities that appear with the concentration of activities. In addition, according to SaintEtienne, Prager and Thisse (2009: 59): "The economy of creativity is based on entrepreneurship, talent and knowledge and draws its main forces in major cities". Gastronomic commons use creativity and according to Bailly and Hussy (1991), Paris and Lyon play an essential role in the concentration of starred restaurants. In 2010, these two cities own $10 \%$ of the French restaurants selected in the Michelin Guidebook and $14 \%$ of the French starred establishments. Thus, the second explanation to the polarization of gastronomic establishments is that the restaurants are located in cities exercising a strong power to attract customers, workforce, and based near the most important French terroirs 
(production areas of the gastronomic common-pool resources, involving lower tariffs for the transport).

In France many producers are working on the gastronomic market. And we can see spatial concentrations of them in big touristic cities and in the main areas producing gastronomic inputs. Consequently these polarizations involve cooperation and competition between restaurants and are organized in a special form of district (Marshall, 1890) and especially as a particular cultural district (Santagata, 2006). We can thus define gastronomic district as based:

- On specific resources: farm produce and foodstuffs, heritage of knowledge and know-how (passed on by families and trainings), heritage of creativity (owned and developed by the chefs), heritage of conventions (tastes and preferences), heritage of institutions (experts, guides, critics, prestigious associations) and organizations (associations, clubs or gastronomic brotherhoods).

- On synergies: they imply a location, a market, specific skills, and generate economies of scale and of scope.

In Marshallian districts (Marshall, 1890) and Italians ones (Trigilia 1986; Garofoli, 1992, Brusco, 1992; Becattini, 1992a, 1992b), economic efficiency is related to the integration of firms within a given geographical area. According to Porter (1998, 2000), geographic concentration leads to interactions and competition and thus innovation and productivity. In cultural districts (Scott, 2000; Valentino, 2001; Santagata, 2002, 2004a, 2004b, 2006; Greffe, Plieger and Noya, 2005), economic development is based either on the dual interaction between place and heritage goods or on the relationship between the place and creative activities. Gastronomic districts are conversely based on the interaction of all the three 
elements of place, heritage and creativity. Their organization is illustrated by the following figure (Bonnard, 2011).

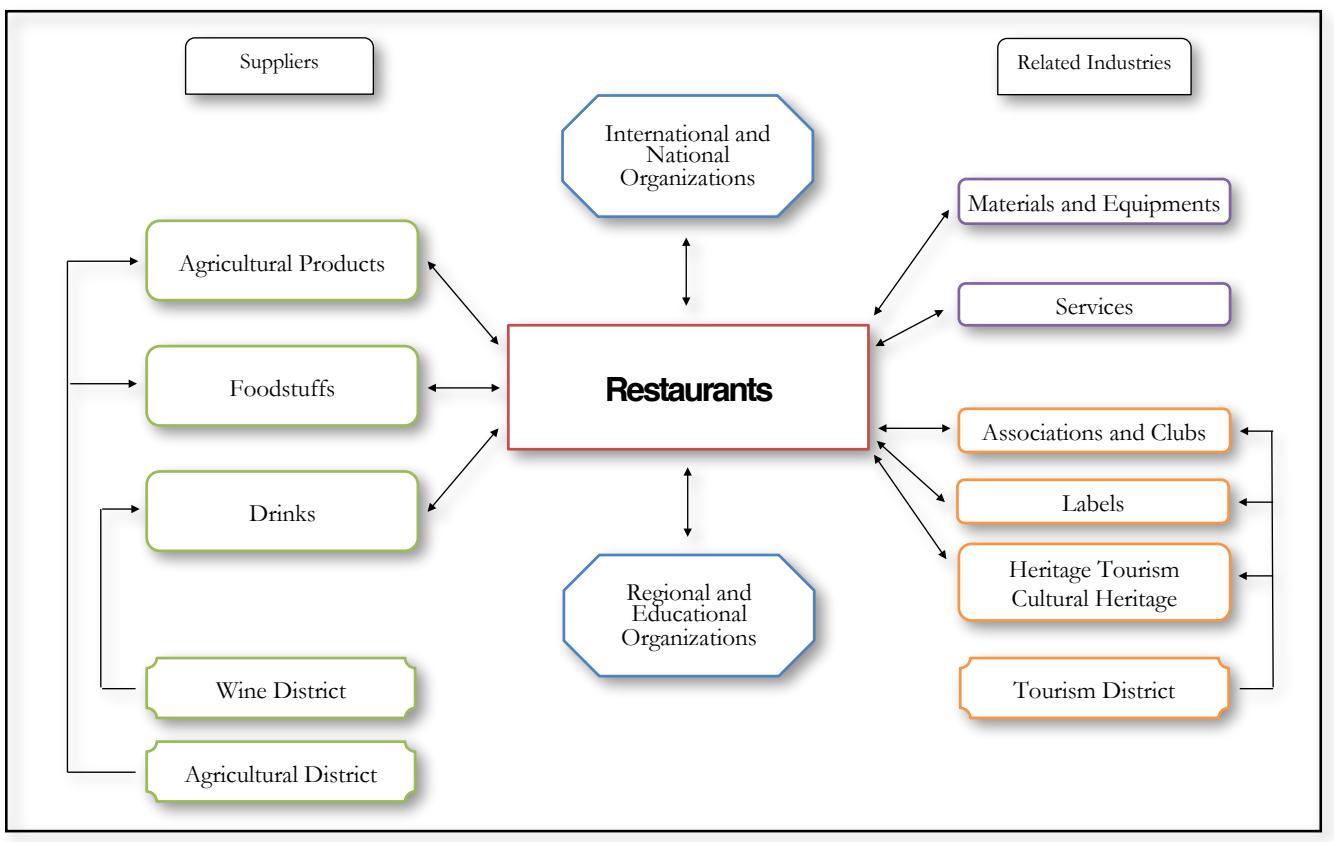

Figure 1: Anatomy of the French Gastronomic Districts

Firstly, a gastronomic district is composed of a productive core: the restaurants and their chefs. They are located on a limited territory which implies competition but also cooperation (redirecting client, equipment loans, etc.). Chefs are members of national and regional associations that share their ideas, recipes, defend their profession, and so on, thereby contributing to the development of a common culture. The second level is composed of the producers of the gastronomic commons that is to say the restaurants suppliers. The transactions between food producers and restaurants take place on markets or in halls and promote interactions among the stakeholders of the district. Moreover, the producers of gastronomic inputs are also organized in cooperatives or with labels. They all wish to be the main suppliers of grands chefs, and as competing they increase the quality of the products. 
Then at the third level of the gastronomic district, we find the suppliers of equipment goods and miscellaneous services for hotels and restaurants besides the production process. A gastronomic district generates several related activities whose development and weight are very important. Thus, a gastronomic district is linked to the touristic heritage of the area in which it is located and is embedded in a system also comprising agricultural districts, wine districts and tourism districts. Finally, the fourth level of this kind of district consists of the culinary institutions, local and educational organizations, which organize, maintain and promote the gastronomic culture.

A more precise enquiry shows that the territorial areas in which we observe the gastronomic districts in France depend on two models. The Parisian model, or a metropolitan area, illustrates the first one. The gastronomy of such place is polarized in the neighbourhoods that have a strong cultural heritage. Indeed, this heritage attracts tourists, who will then consume the gastronomies present in that area. In this case, the supply of gastronomic resources is not only local but also national and international. The second model may be characterized by the case of the Lyon area, considered for its quality of regional culinary productions and resources. The cuisine of this area is based on a real and important gastronomic heritage, which gives it the character of a French regional cuisine. Terroirs located nearby provide several local high quality products to the chefs located in the centre of the biggest city of the area.

Therefore, both types of gastronomic districts emerge and develop according to different patterns. The gastronomic district of Lyon is the result of a process of spontaneous development, based on the initiative of regional chefs who have organized themselves. Once constituted, the district turns towards tourism to expand itself. On the contrary, from the very beginning, the Parisian gastronomy model has developed from a pre-existing demand based 
both on the concentration of the French social elite and tourism favoured by the reputation of French gastronomy. Parisian tourism institutions have also strongly contributed to the creation and the development of food tourism in Paris.

Thus, restaurants derive substantial benefits from grouping as a gastronomic district. Agglomeration and co-localization provides dense linkages that enable the dissemination and flow of information, generating numerous new ideas, and producing a climate leading to innovation and cooperation and therefore maintain the dynamics of gastronomic commons. It enables the provision of various inputs at lower cost through personalized relationships. It leads to the creation of an efficient labour market and promotes the mobility of labour between firms and the creation of new restaurants. It allows participants to achieve economies of scale, external economies and other benefits related to the immediate environment of the district.

\section{Using gastronomic commons and contributing to them}

In chapter one the difference between using common resources and contributing to them has been considered as the first social dilemma affecting cultural commons. In the case of gastronomic commons this dilemma is peculiarly important.

The actors of the gastronomic area can draw from the set of resources shared in the gastronomic commons. Some resources are strictly linked to specific heritages (for instance some specific recipes), some others were connected to specific heritages but have been integrated into other ones (for instance steam cooking, coming from the Chinese cuisine is now used in several other cuisines) whereas the last ones are only a piece of the shared resources. The last two categories can be shared and used by everyone. The first resource, cultural gastronomic heritages, has an increasing and specific value beyond shared resources 
characteristics because they express social and cultural identity. In a market system the actors of the gastronomic field use them as capital and benefit from their productivity. That also implies competition between particular heritages and has some implications on the access rights. Although almost all the resources are in open access, cultural barriers may hinder their use. Nevertheless, now, the circulation and the use of culinary heritages become easier with globalization which extends the global character of each local culinary culture. At the same time this movement increases the value of the gastronomic commons and heritages.

The use of gastronomic commons enhances the value of the final output. Craft knowledge, within the restaurants and mainly the grands restaurants, is passed down to generations of workers and this means they have the skills to perform sophisticated technical operations. Moreover, to become first class chefs, cooks need the support of top teams of suppliers offering the finest products (meat, dairy, vegetables, etc.). Close links are maintained and developed by the gastronomic districts. This refers to the community dimension underlined in Chapter one. And popular gastronomy also uses the knowledge developed by common heritages (how to make a bouillabaisse in Marseille or lasagne in Bologna?). Both the history of the grands restaurants closely associated with the legend of grands chefs like Alexandre Dumaine, Fernand Point and Alain Ducasse, who entered the pantheon of gastronomy, by passing on their creative knowledge to new generations of chefs, and the cult of creation are a major incentive to creativity. Moreover guilds preserve and transmit the traditions of craft. They require their members to become "journeymen" and to travel to perfect their craft. That enables cooks to exchange their experience and their creative and heritage knowledge. Chefs have a huge stock of recipes and can introduce creativity into their dishes by "revisiting" old recipes. So, heritage plays a key role as a source of inspiration, a source of production and of contemporary creativity. Then, gastronomy uses creativity and 
heritage simultaneously, joins private and public contributions, and, thus, generally benefits from a virtuous circle: goods, knowledge, ideas produced constitute kinds of heritage that, in return, favour creativity. By mimicking the Sraffa framework - Production of Commodities by Means of Commodities (1960) - we can speak of the production of gastronomic creative goods and heritages by creative goods and heritages. So, gastronomic commons and gastronomic heritages are not fixed but evolve through time. Private practices allow and accompany this movement; numerous individual actors may add to heritages but also may re-orient the path: chefs of course but also opinion leaders (e.g. sovereigns...) and authors of gastronomic books and even gastronomic experts.

The actors of the gastronomic field usually privately appropriate the benefits arising from the knowledge and recipes, but gastronomic commons provides also collective benefits. Culinary and gastronomic styles, which are a collective creation, enhance the position of the cuisines that present them. For instance the French restaurants collectively benefit from the image given by the French heritage insofar as this activity is deeply rooted in the French identity. Indeed, many foreign tourists come to France and Italy to eat in their most famous restaurants; and at the same time, French and Italian restaurants abroad attract many lovers of the French and the Italian ways of life. Moreover, gastronomy boosts tourism and products, like other cultural goods, many pecuniary externalities: museum visits, hotel bookings, wine tasting and sales, terroir products, and so on. It is the same for the existence of a heritage of tastes and preferences, i.e. a common reading of signs and symbolic values. It produces homogeneous representations. In a market of sign-goods like the gastronomic market, it allows demand to adjust to supply. It makes gastronomic dishes understandable; it makes creation credible; it legitimates creative work such as gastronomic creation; it leads to an image heritage. Moreover, it provides a competitive advantage in world markets. 
However free riding behaviours -remember the truffle soup- can exist and discourage creation. That implies considering the problem of access rights. So doing, we have to distinguish different periods. As already seen in the previous point, in the Middle Ages market relations were limited, gastronomy was mainly conservative and the innovation rate very low. The public component of gastronomic production was dominant; one could not identify any individual contribution (who invented the bouillabaisse or the pizza?). Indeed early recipe books were collections of traditional recipes (no specific author of recipes could be wellidentified and such books were often published anonymously) and made no statement of innovations. Non-professional cooks shared culinary and regional gastronomic commons. In the professional segment, dedicated to aristocratic cooking, chefs also used tradition and gastronomic commons. Thus property rights applied to gastronomy did not matter.

Later on, with Court society, things did not change for popular cooking but did for the aristocratic one. Some chefs began to be famous - Vatel for instance - and they developed a very sophisticated and innovative cuisine, including new recipes and new types of presentation, with a real culinary design. So the contribution of the individuals to the extension of gastronomic commons and heritages was not trivial. Nevertheless there were no problems of property rights because chefs participated in a system of personal relations with institutional liaisons and hierarchies (Barrère and Santagata, 1998). The creative chefs were well-known within the narrow circle of luxury craftsmen and the spreading of their innovations increased their reputation capital.

Eventually, with the development of the 'restaurant', market relations rule a notable part of the gastronomic supply. The low and the intermediate segments mainly draw from culinary and gastronomic commons and heritages. The top segment (for instance the starred Michelin restaurants) is conversely innovative. From the standard point of view of Property 
Rights theory individual contributions should be protected. Nevertheless a lot of problems arise. It would be necessary to identify individual innovation, then to separate it from the collective working of the profession, from the cultural atmosphere and from the commons and heritages. Most of the time creation is collective (the chef but also his/her kitchen team...). So, the legal protection devices appear to be unsuited to or difficult to be implemented in gastronomy. Chossat (2009) showed that intellectual property rights (IPR) could not be applied to food and especially to the recipes that can be considered as lists of ingredients and not as intellectual works by French courts. Buccafusco (2008) admitted it also in the case of America. Cunningham (2009) explores IPR in the culinary field and more precisely from the recipe-theft point of view. The author underlines the costs of "copyrightability" of recipes and the risk to hinder competition between chefs and the potential decrease in creativity for all the market for gastronomy. Plus the lack of legal protection for private and then public gastronomic goods and services may be compensated for by the implementation of admitted practices like norms-based IP highlighted by Fauchart and von Hippel (2008) for the case of French gastronomy. This kind of alternative system based on norms accepted by a community of actors frames copy behaviours by shaming and loss of status for violators of IP (Fauchart and von Hippel, 2008: 197). In this set of ideas, guilds as collective actors seem to play a keyregulating role between individual and collective practices and then to link private practices to gastronomic commons.

We are now entering a new period with the development of new technologies (vacuum cooking, deep-freezing, and other mass-production technologies) that allow the standardization and the industrialization of cooking. Then industrial cuisine can supply gastronomic or pseudo-gastronomic services. Households represent a first outlet but, now, and more and more, a lot of restaurants serve both home made dishes and industrial dishes they 
buy from new food companies. These firms are able to provided them with standard quality for sophisticated dishes. They mimic the street fashion system that copies Haute Couture and luxury ready-to-wear models: they copy the great chefs' recipes and sell dishes looking like gastronomic ones; they are not comparable with the famous restaurants but their prices are far lower. Then a new problem of IPR arises. Industrial food firms develop industrial and technical innovation but, for the recipes and the definition of new dishes, they draw from the gastronomic commons. They benefit from the creativity of chefs without giving them any money. In some cases, to avoid legal disputes, and to increase their reputation, they prefer to hire famous chefs. However, if the system goes on, growing new stakes are going to appear. The top level of gastronomy, with the famous restaurants, would concentrate creative labour that would be freely used by the industrial segment. The first one would support increasing costs whereas the second would indirectly take advantage of it; that would lead to a problem for reproducing creativity.

\section{Evolution and reproduction of gastronomic commons}

In the case of gastronomic commons the second dilemma defined in chapter one depends on the mix of private and public characteristics, private and public goods that gastronomic commons and gastronomic heritages represent. Two key and interrelated questions emerge. The first one is that of the enrichment and decline of culinary heritages. The second one is that of competition among diverse cultural culinary heritages.

Culinary and gastronomic heritages gather recipes and know-how in free access but they evolve with the consolidation of common culinary practices (e.g. traditional dishes) and 
through the private practices of chefs who change recipes, ingredients, proportion thus means creating new ways of cooking from secular traditions.

Some actors of the gastronomic field have a conservative behaviour. It is mainly the case for popular and regional cuisines. Their heritages are kept by the traditional ways of family education and give the key role to women, with a transmission from the mother to the daughter. The collective feasts (e.g. le 'pèle-porc') contributed, even through emulation, to the respect of tradition and of local identity. The books dedicated to the domestic science and studied by young girls (in écoles ménagères, where they learnt how to become housewives) contributed to stabilize tradition and to reproduce these conservative commons. At the beginning of the $20^{\text {th }}$ century, the case of the Mères Lyonnaises is also very interesting because popular traditional cooking influenced the way of cooking of the French gourmet restaurants.

On the contrary, for gastronomic commons, current creativity uses the creativity of the past that has been accumulated to constitute a heritage while, simultaneously, adding to it. Chefs, as private actors living in a given gastronomic environment - say a given technical knowledge-, are changing the gastronomic commons in the long run thanks to their practices. Most of the time they modify preparations thanks to a trial and error process ${ }^{4}$, but they also introduce new recipes, new ways of preparing produce, new styles, according to cultural evolution. For instance, we went from the cuisine of the Middle Ages, based on the abundance of dishes all very well presented but generally with poor taste and most of the time eaten cold, to an aristocratic cuisine limiting the number of dishes and preferring excellence of flavour to presentation.

\footnotetext{
${ }^{4}$ One of the most famous examples of trial and error process is the one of the tarte Tatin. The legend tells that one of the two sisters Tatin in love with a client of the restaurant dropped the apple pie and baked it backwards.
} 
Over the centuries gastronomic history has been punctuated by numerous controversies occurring in cycles. As in many other fields ancients who want tradition to continue oppose to moderns refusing circularity. For instance, during the $17^{\text {th }}$ century, in France the dispute pitted L.S.R (modern) ${ }^{5}$ against La Varenne (ancient). The moderns criticised the use of fanciful names of dishes and refused the sophisticated culinary preparations proposed by the ancients (Poulain et Neirinck, 1995: 28). More recently, i.e. in the last quarter of the $20^{\text {th }}$ century, the advent of nouvelle cuisine is another illustration. The common element between these often "theoretical" disputes is the reason for the opposition, i.e. the struggle for the paradigmatic power: who will determine and influence tomorrow's cuisine? Gastronomic commons evolve through these disputes and according to the temporary winner.

The French gastronomic commons is the result of a very slow movement led by the chefs, especially Antonin Carême and Auguste Escoffier, in the 19th century. These two chefs set the French cuisine paradigm all over the world. They invested a lot of money and were the real architects of the transformation of a culinary practice into a cultural norm. According to Parkhurst-Ferguson (2004: 50) a chef like Antonin Carême reinvented cuisine, not because he has created a sauce he gave his name too, but more precisely because he created a coherent system of sauces, soups, pastries, cooked vegetables, etc. With him was born the classic culinary paradigm that transformed the French gastronomic commons, which began to spread all over the world. At the same time, Auguste Escoffier developed a system of French cuisine based on mutuals linked to international palaces hiring French cooks and more broadly French staffs, (e.g. Société Mutualiste de Paris). This dense network put France at the

\footnotetext{
${ }^{5}$ L.S.R are the initials of an unknown chef who published in 1674 « L'art de bien traiter ».
} 
forefront of gastronomic nations during many decades. At that time no other nation could only represent a credible alternative to the French supremacy.

As indicated above, gastronomic commons do not only derive from courts and sovereigns. They also have a popular dimension that may influence the upper one and viceversa. Moreover, at the turn of the $18^{\text {th }}$ and $19^{\text {th }}$ centuries, the political and economical advent of bourgeoisie, uninitiated to table manners (unlike aristocracy), conducted the emergence of a gourmet intermediary function, that is to say an expert. For instance Brillat-Savarin with his Physiologie du goût (1848) and Grimod de la Reynière with his Manuel des Amphitryons (1808) contributed introducing the bourgeoisie to table manners as well as inculcating gastronomic commons. After them appeared the restaurant critic who standardized the assessment of gastronomic quality and defined and spread French gastronomic norms. Experts play a large part in the orientation of gastronomy by supporting some innovations and defining the leading trends. The French 'nouvelle cuisine' movement succeeded through an alliance between young chefs and new gastronomic critics and magazines. Today the success of molecular cuisine derives from the new connection between scientists (mainly the physicist Hervé This in France) and chefs (Pierre Gagnaire, Ferran Adria, Thierry Marx, Juan Mari Arzak).

Thus the enrichment of culinary heritages is favoured by two conditions. It first depends on the degree of sophistication of the cuisine. The more developed the cuisine, the more the intrinsic logic of artistic creative behaviour spreads out. It also depends on the degree of competition between chefs. The higher it is the higher the degree of creation. With the development of gastronomic restaurants cuisine evolves towards a creative paradigm. After the years of the 'nouvelle cuisine' we entered in the years of the 'creative cuisine'. And for the chefs it is now 'to create or to die'. On the contrary, with the race for creativity, the 
costs of producing new dishes and new recipes are growing. Then free riding behaviours increase and can lead to impoverishment of common heritages with the risk of gastronomic commons remaining unchanged in the long run and thus possibly declining.

The question of Property Rights is recurrent. A first issue regards the protection of foodstuffs and know-how insofar as the risk of extinction of some ingredients constituting gastronomic commons in a given area is at stake. For example some plant resources are endangered and some have even disappeared because of their failure to adapt to changing societies and to contemporaneous ways of production. Through the process of hybridization plant varieties become certainly more resistant and have increased their yield, but the number of cultivated varieties has drastically reduced through this plant breeding process. So the question of reducing diversity arises but is likely to be curtailed by the introduction of a system of property rights. Another issue is the protection of creativity. We said it is actually difficult. Moreover the balance is fragile in that protecting can theoretically lead to deadlocks in resources use. A strong link can be made with the tragedy of anti-commons of Heller (1998, 2008) and the loss of economic efficiency: too many property rights lead the system to collapse.

Local and national gastronomic commons are really in competition. Heritages give competitive advantages. Nevertheless they may build obstacles in the way of development. Norms and principles structure heritages and give them coherence and closure, increasing their difference from a simple stock of shared resources. So, strong heritages institutionalize given practices and given tastes, creating barriers to changes. It becomes more difficult to add new foodstuffs to them or new styles that differ from the logic of the heritage. As they are strongly encapsulated in a specific culture, linked to a specific history, their rigidity hampers 
their adaptation to cultural changes; lock-in phenomena are developing. At the same time, the diverse cuisines, even if they belong to a world of shared gastronomic resources, are competing. Some, more flexible, are quickly capable of adaptation; new styles appear and challenge the old hierarchy. For instance new gastronomic countries, explicitly Spain, Germany and England, question the French supremacy. In addition, the inertia of the French experts seems to be largely invoked for this disaffection with French cuisine and then gastronomic commons. According to Poulain (2005), experts have become gastronomic heritage managers. From this point of view French guidebooks appear as "chambres d'enregistrement" of French gastronomic concepts rather than as referees open to the world. When the competitiveness of other cuisines was low, the difficulty to adapt the old heritage of the French cuisine had no strong consequences. After a while the 'nouvelle cuisine' succeeded in adapting the old aristocratic and popular cuisine based on heavy sauces and pretentious presentations. But, with the emergence of new gastronomic countries, the competitive area changed.

Now, in gastronomy, new values are emerging. Sophistication is questioned by the craze for nature and natural products. For instance, vegetables used to be considered in France as common food but, today, they become a basis for valued dishes; in his famous restaurant L'Arpège (Paris) Alain Passard presents vegetables served with meat. Ecological values are in opposition to wasting and influence cooking. In the same way, the globalization process mixes cultures and heritages. Culinary heritages can be used out of their original area, products, sauces, spices and way of cooking are everywhere at everybody's disposal, transport costs are strongly diminishing. Consumers are interested in new experiments; they seek to meet new culinary heritages. Multiculturalism grows and world fusion cuisine is spreading. 
Curiously, the elitist restaurant is no longer the unique dominant model but a kind of gastronomic pluralism develops; a new category of restaurants emerges: extra-ordinary ways of cooking do not remain the unique symbol of luxury and taste. Creativity mixed with ordinary foodstuffs and setting attracts a wider less rich audience, looking for new codes such as pure and healthy products, less sophisticated settings and so on. This "low cost gastronomy" (according to the words of Alain Senderens) takes an active part in the democratisation and the mass-consumption of gastronomy (Barrère, Bonnard and Chossat, 2010). Conversely the Old French model of gastronomy, based on the leader role of the grand restaurant can no longer pretend to be the reference to organize the world gastronomy: the competition between old cuisines and emerging cuisines will also involve the institutional form of consuming gastronomy.

\section{References}

Bailly A. S. and C. Hussy 1991 “La Diagonale Gourmande”. Mappemonde, 2/91.

Bailly A. S. and J. H. P. Paelinck 1992 "La localisation de restaurants de marque : les critères implicites dans l'information du Guide Michelin”. Annales de Géographie, Vol. 101, n563, pp. 85-90.

Barrère C. 2004 Les dynamiques économiques du patrimoine. In Barrère C. Barthélémy D. Nieddu M. Vivien F-D. (Sous la Direction de), Réinventer le patrimoine, L'Harmattan, Paris, pp. 109-120. 
Barrère C. and W. Santagata 1998 Defining Art: from the Brancusi Trial to the Economics of Artistic Semiotic Goods in International Journal of Arts Management, 2: 28-38.

Barrère C., Q. Bonnard and V. Chossat 2010 "Democratization in the Gastronomic Market: From Michelin Stars to Michelin 'Bibs"”, The $16^{\text {th }}$ ACEI Conference, 9th $-12^{\text {th }}$ June, Copenhagen, Denmark.

Becattini G. 1992a Le district marshallien : une notion socio-économique. In Benko G. Lipietz A., Les régions qui gagnent. Districts et réseaux : les nouveaux paradigmes de la géographie économique, PUF, Paris, pp. 37-39.

Becattini G. 1992b “Le district industriel : milieu créatif”. Espaces et sociétés, n66-67, pp. 147-163.

Beaugé B. 2010 "Sur l'idée de nouveauté en cuisine". Mode de recherche, Gastronomie, cycles de mode et consommation, Institut français de la mode, Paris, n¹3, pp. 3-11.

Bilon-Hoefkens I. and G. Lefebvre 2004 "L'innovation dans les régions françaises : première analyse des performances générales et des biotechnologies en particulier”. $X L^{\circ}$ Colloque de l'Association de Science Régionale de Langue Française, Bruxelles, Septembre.

Bonnard Q. 2011 Les districts gastronomiques: des districts d'un nouveau type. Thèse, Université de Reims Champagne Ardenne, December 2011.

Bourdieu P. 1979 La distinction. Editions de Minuit, Paris

Brillat-Savarin J. A. 1848 Physiologie du goût, Gabriel de Gonet, Paris.

Brusco S. 1992 Small firms and the provision of real services. In Pyke F. Sengenberger W. Editions, Industrial Districts and Local Economic Regeneration, International Institute for Labour Studies, Geneva, pp. 177-196. 
Buccafusco C. J. 2008 “On the Legal Consequences of Sauces: Should Thomas Keller's recipes per se Copyrightable ?", Cardozo Arts and Entertainment Law Journal, 24, pp. 1121-1156.

Cantillon R. 1755 Essai sur la nature du commerce en général. Edition de l'I.N.E.D., Paris, 1952.

Chossat V. 2001 Les processus de sélection sur un marché, le cas de la grande cuisine. Thèse pour le doctorat en sciences économiques, Université de Reims, France.

Chossat V. 2009 “Questioning the author's right protection for gastronomic creations: Opportunities versus possibilities of implementation". Creative Industries Journal, 2(2), pp. 129-142.

Christaller W. 1933 Die Zentralen Orte in Suddeutschland, Iéna. Traduction anglaise : Baskin C. W. 1966. Central places in Southern Germany, Englewood Cliffs, Prentice-Hall.

Colloredo-Mansfeld R. 2005 Consumption in A Handbook of Economic Anthropology, ed. by J.G. Carrier, Edward Elgar, Cheltenham.

Cunningham E. 2009 "Protecting Cuisine Under the Rubric of Intellectual Property Law: Should the Law Play a Bigger Role in the Kitchen ? Journal of High Technology Law, 21, pp. 21-51.

Douglas, M. 1966 Purity and danger: an analysis of the concepts of pollution and taboo. Praeger New York.

Douglas, M. and B. Isherwood 1979 The world of goods. Basic Books. New York.

Elias, N. 1973 La civilisation des mours. Calmann-Lévy, édition Presses Pocket, Paris.

Fauchart E. and E. von Hippel 2008 "Norms-Based Intellectual Property Systems: The Case of French Chefs", Organization Science, 19(2), pp. 187-201.

Fischler C. 1993 L'homnivore. Paris: O. Jacob. 
Garofoli G. 1992 "Les systèmes de petites entreprises: un cas paradigmatique de développement endogène". In Benko G. Lipietz A., Les régions qui gagnent. Districts et réseaux : les nouveaux paradigmes de la géographie économique. PUF, Paris, pp. 57-80.

Greffe X., S. Pflieger and A. Noya 2005 La Culture et le Développement Local. Organisation de Coopération et de Développement Économiques OCDE, OECD Publishing.

Grimod de la Reynière A. B. 1808 Manuel des Amphitryons, Capelle \& Renand, Paris.

Heller M. 1998 The Tragedy of the Anticommons, Harvard Law Review 111, 621; January.

Heller M. 2008 The Gridlock Economy: How Too Much Ownership Wrecks Markets, Stops Innovation, and Costs Lives. Basik Books.

Helpman E. 1998 The size of Regions in D. Pines, E. Sadka and I. Zilcha (eds.) Topics in Public Economics. Cambridge University Press, New York, pp. 33-54.

Krugman P. 1991 Geography and Trade. MIT Press, Cambridge, Mass.

Lévi-Strauss C. 1964 Le cru et le cuit, Plon, Paris.

Lösch A. 1940 Die räumliche Ordnung der Wirtschaft, Iéna. Traduction anglaise : Fischer G. 1954. The Economics of Location, Yale University Press New Haven.

Madison M. J., B. M. Frischmann, and K. J. Strandburg 2010 "Constructing Cultural Commons in the Cultural Environment”. Cornell Law Review, Vol. 95: 657-710.

Marshall A. 1890 Principles of Economics. London, MacMillan, 8th Edition, 1920. Traduction française : Sauvaire-Jourdan F. 1906. Principes d'économie politique.

Ostrom E. 1990 Governing the Commons: The Evolution of Institutions for Collective Action. Cambridge University Press.

Parkhurst-Ferguson P. 2004 Accounting for Taste: the Triumph of French Cuisine. Chicago: The University of Chicago Press. 
Porter M. 1998 "Clusters and the new economics of competition". Harvard Business Review, November-December 1998, pp. 77-90.

Porter M. 2000 "Location, Competition, and Economic Development: Local Clusters in a Global Economy”. Economic Development Quarterly, Vol. 14, n¹, pp. 15-34.

Poulain J.-P. 2005 Sociologies de l'alimentation, les mangeurs et l'espace social alimentaire, PUF, Quadrige, Paris.

Poulain J.-P. and E. Neirinck 1995 Histoire de la cuisine et des cuisiniers. Editions LT Jacques Lanore, Paris.

Rappaport, R. A. 1984 (1968) Pigs for the ancestors: ritual in the ecology of a New Guinea people. Yale University Press, New Haven.

Saint-Étienne C., Prager J.-C. and J.-F. Thisse 2009 Les Fondements d'une stratégie dynamique d'aménagement du territoire. Rapport au Président de la République, Paris.

Santagata W. 2002 "Cultural districts, property rights and sustainable economic growth". International Journal of Urban and Regional Research, n²6, pp. 9-23.

Santagata W. 2004a "Cultural district and economic development”. Mimeo, EBLA Center, Torino University.

Santagata W. 2004b Creativity, fashion and market behavior. In Power D. Scott A. J. Editions, Cultural Industries and the Production of Culture, Routledge, London, pp. 75-90.

Santagata W. 2006 Cultural districts and their role in developped and developing countries. In Ginsburgh V. Throsby D., Handbook of the Economics of Art and Culture, NorthHolland, pp. 1101-1119.

Scott A. J. 2000 The Cultural Economy of Cities: Essays on the Geography of ImageProducing Industries. Sage Publications, London. 
Segers K. and E. Huijgh 2007 "Clarifying the Complexities and Ambivalence of the Cultural Industries". Working Paper $n^{\circ} 8$, Centre for Media Sociology, Free University of Brussels.

Sraffa P. 1960 Production de marchandises par des marchandises. Traduction française, Paris, Dunod, 1970.

Terrier C. 2006 Mobilité touristique et population présente. Les bases de l'économie présentielle des départements. Édition Direction du tourisme.

Thisse J.F. and T. Van Ypersele 1999 "Métropoles et concurrence territoriale". Économie et Statistiques, 326-327 (6/7), pp. 19-30.

Throsby D. 2010 The Economics of Cultural Policy. Cambridge University Press.

Towse R. 2010 A Textbook of Cultural Economics. Cambridge University Press.

Trigilia C. 1986 "Small-firm development and Political subcultures in Italy". European Sociological Review, $\mathrm{n}^{\circ} 1$, pp. 161-175.

Valentino P. 2001 I distretti culturali : Nuove opportunità di sviluppo del territorio. Associazione Civita, Roma.

Von Thünen J. H. 1826 Der Isoleirte Staat in Beziehung auf Landwirthschaft und Nationalökonomie, oder Untersuchungen über den Einfluss, den die Getreidepreise, der Reichtum des Bodens und die Abgaben auf den Ackerbau ausüben, Volume 1 : and Der Isolierte Staat..., Volume II : Der Naturgeässe Arbeitslohn und dessen Verhältnis zum Zinsfuss und zur Landrente. Traduction anglaise du Volume I : Wartenberg C. M. 1966 Isolated State. Pergamon Press, New York.

Weber A. 1909 Über den Standort der Industrie. Traduction anglaise : Friedrich C. J. 1929 Theory of the Location of Industries. The University of Chicago Press, Chicago. 